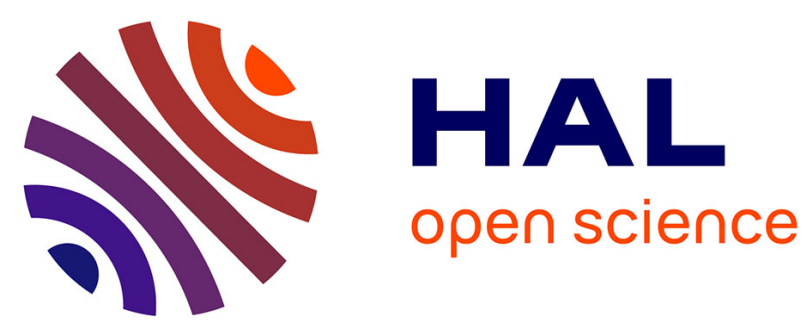

\title{
The stereoisomerism of second generation anticoagulant rodenticides - a way to improve this class of molecules to meet the requirements of society?
}

Virginie Lattard, Etienne Benoit

\section{- To cite this version:}

Virginie Lattard, Etienne Benoit. The stereoisomerism of second generation anticoagulant rodenticides - a way to improve this class of molecules to meet the requirements of society?. Pest Management Science, 2018, 75 (4), pp.887-892. 10.1002/ps.5155 . hal-01851818

\author{
HAL Id: hal-01851818 \\ https://hal.science/hal-01851818
}

Submitted on 7 Feb 2020

HAL is a multi-disciplinary open access archive for the deposit and dissemination of scientific research documents, whether they are published or not. The documents may come from teaching and research institutions in France or abroad, or from public or private research centers.
L'archive ouverte pluridisciplinaire HAL, est destinée au dépôt et à la diffusion de documents scientifiques de niveau recherche, publiés ou non, émanant des établissements d'enseignement et de recherche français ou étrangers, des laboratoires publics ou privés. 


\title{
The stereoisomerism of second generation anticoagulant rodenticides: a way to improve this class of molecules to meet the requirements of society ?
}

\author{
Virginie Lattard ${ }^{1}$, Etienne Benoit ${ }^{1}$
}

\begin{abstract}
Second generation anticoagulant rodenticides (SGAR) are generally highly efficient for rodent management even towards warfarin-resistant rodents. Nevertheless, because of their long tissue-persistence, they are very associated with non-target exposure of wildlife and have been identified as 'Candidates for Substitution' by the European Union's competent authority. A promising way to reduce ecotoxicity issues associated to SGAR could be the improvement of SGAR based on their stereoisomery, and due to this improvement, positioning about SGAR might be reconsidered.
\end{abstract}

Keywords

Second generation anticoagulant, stereoisomery, Vitamin K epoxide reductase, persistence, resistance, ecotoxicity

${ }^{1}$ USC 1233 RS2GP, VetAgro Sup, INRA, Univ Lyon, F-69280, 1, avenue Bourgelat, 69280 Marcy l'Etoile, Lyon, France

*Corresponding author: virginie.lattard@vetagro-sup.fr

\section{Contents}

1 ARs : candidates for substitution

2 Why are SGARs still interesting and promising molecules?

3 A way to improve AR molecules: their stereoisomerism

4 Numerous examples of different biological properties among stereoisomers

5 What about SGARs ?

6 Conclusions

Acknowledgements

References

\section{ARs : candidates for substitution}

The 8 Anticoagulant Rodenticide (AR) active substances have been identified as "Candidates for Substitution" by the European Union's competent authority as a result of their evaluation as part of the Biocidal Products Regulation 528/2012. The concerning 8 AR's are as follows: brodifacoum, bromadiolone, chlorophacinone, coumatetralyl, difenacoum, difethialone, flocoumafen and warfarin. Why were they identified as such? Two major problems are associated with their use, the phenomenon of widespread resistance to some of these molecules in some rodent populations ${ }^{1-5}$ and their ecotoxicity ${ }^{6-8}$.
The first generation ARs -FGARs- including warfarin, chlorophacinone, coumatetralyl, pindone and diphacinone have been used since the late 1940s. Since their first use, rodent management has very often relied on the use of these molecules. They have therefore been used intensively in many countries of the world ${ }^{9}$. This intensive use has led to a selection of rodent strains resistant to ARs. Resistance was first detected in brown rats in $1958^{10}$ and in house mice in the early 1960 's ${ }^{11}$ in the United Kingdom. Since this initial observation resistance has been reported worldwide, in many European countries, in the United States ${ }^{12}$, in Canada ${ }^{13}$, in Japan ${ }^{14}$ and in Australia ${ }^{15}$. The emergence of resistance to FGARs has led to the development of a second AR generation (bromadiolone, difenacoum, brodifacoum, difethialone, flocoumafen) sometimes subdivided into 2 generations, generation 2 including bromadiolone and difenacoum and generation 3 including brodifacoum, difethialone and flocoumafen. This subdivision is explained by the fact that if resistance phenomena have been described for bromadiolone ${ }^{3,4}$ and difenacoum ${ }^{3,4}$, no resistance has yet been described for the other 3 molecules.

In addition to the resistance phenomena, ecotoxicity of ARs is also an issue which has contributed to identify them as candidates for substitution. Indeed, exposures or intoxications to AR have been frequently reported in wildlife around the world, in mammal species such as European mink (Mustela lutreola), urban bobcat (Lynx rufus), stoat (Mustela erminea), weasel (Mustela nivalis), red fox (Vulpes vulpes) and wild 
boar (Sus scrofa) $)^{7,16-19}$ and as well in many birds such as red kite (Milvus milvus), Buzzard (Buteo buteo), kestrel (Falco tinnunculus), barn owl (Tyto alba) ${ }^{6}$. Exposure may be primary when non target species directly eat the bait8. But most often, exposure of wildlife is secondary due to ingestion of poisoned rodents by predators or scavengers. ${ }^{6,7,16-19}$ This secondary exposure is due to the long tissue-persistence of $\mathrm{ARs}^{20}$, especially of SGARs, in rodents and wildlife. Indeed, because SGARs were developed to overcome resistance phenomena, they were designed to kill rodents in a single ingestion which lead to select the most persistent molecules. Thus, secondary poisoning of wildlife associated to the use of SGAR are more often reported.

\section{Why are SGARs still interesting and promising molecules?}

Despite these two major issues associated with the use of ARs and despite their identification as candidates for substitution, the authorizations of the 8 ARs were renewed provisionally at the end of July 2017, until June 30, 2024 by the European Union. These renewals were approved despite the toxicity and the PBT (persistent, bioaccumulative and toxic) nature of these molecules. This decision was taken after the "comparative" evaluation of these molecules with other rodent control methods. Alternative solutions are not yet sufficiently numerous or available to allow the prohibition of AR molecules whose toxicity is nevertheless recognized as problematic.

Alternative chemical solutions must have a delayed effect to overcome the food aversion and the neophobia of the rodents. Currently, all AR molecules have a delayed action due to inhibition of the activation of the coagulation factors by stopping the Vitamin K epoxide reductase complex subunit 1 (VKORC1)-dependent recycling of vitamin $\mathrm{K}^{21}$. They must not be carcinogenic, mutagenic or reprotoxic. ARs are neither carcinogenic nor mutagenic, but on the other hand have very recently been classified as potentially reprotoxic based on data acquired in humans relating to the therapeutic use of warfarin $^{22,23}$.

Because baits can be ingested by children, domestic carnivores and other species, a potent antidote should exist. Vitamin $\mathrm{K} 1$ is a potent antidote for AR poisoning ${ }^{24}$. The alternative chemical solutions should also be readily incorporated in highly palatable baits for rodents with a shelf life of at least 2 years and at low cost. These last criteria are almost all fulfilled by ARs. Of course, new solutions must also not be associated with resistance and ecotoxicity. So far, no miracle solution has emerged. A reasonable and promising proposition is to improve the current ARs by using their stereoisomerism.

\section{A way to improve AR molecules: their stereoisomerism}

A molecule is referred to as chiral if it is not superimposable to its image in a mirror similar to a right and left hand. ${ }^{25,26} \mathrm{Chi}$ rality is linked to molecular asymmetry. An asymmetric center is an atom, usually a carbon atom ${ }^{25,26}$. In a three-dimensional representation, carbon is at the center of a tetrahedron and each summit is occupied by a different substituent (Figure 1). If the substituents of two summits are exchanged, the new structure is no more superimposable with the previous one and the image in a mirror of the first structure corresponds to the second. The two molecules are called enantiomers. Their physical and chemical properties, in a non-asymmetric environment, a common solvent for example, are strictly identical. It is therefore very difficult to synthesize them independently or to separate them analytically. Their light absorption spectrum is identical.

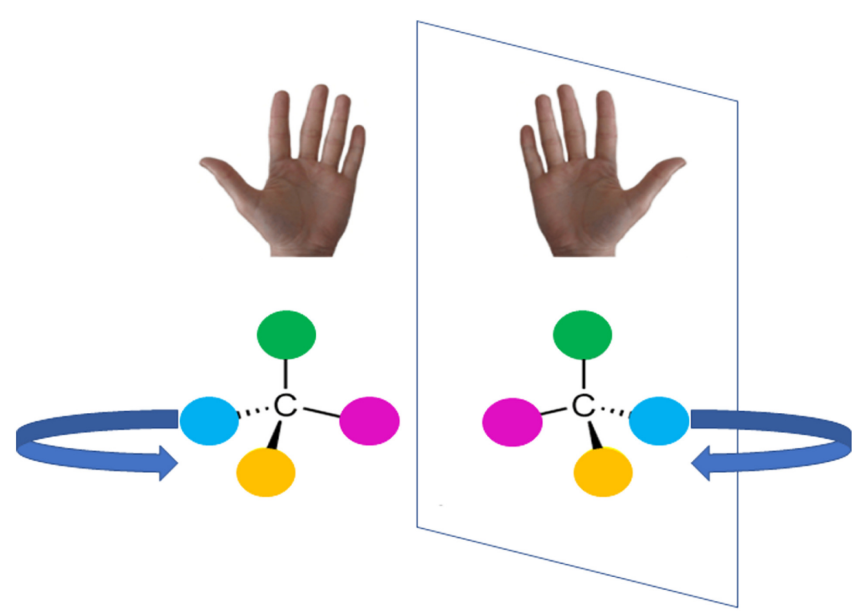

Figure 1. R- and S-enantiomers. An enantiomer is a non-superimposable mirror image.

Nevertheless, in polarized light, one of the two enantiomers will deviate the plane of polarization to the right, it will be qualified as dextrogyre (+), while the other enantiomer will deviate it to the left and will be qualified as levorotatory (-) (Figure 1). The rules of Cahn Ingold Prelog define the absolute configuration of a molecule unambiguously and define the enantiomers R (for rectus, right) and S (for sinister, left) ${ }^{27}$. Nevertheless, these rules are not related to the deviation of the plane of polarization and a structure $\mathrm{R}$ can therefore be dextrorotatory or levorotatory.

Among AR molecules, FGAR molecules (i.e., warfarin, chlorophacinone and coumatetralyl) have one asymmetric carbon atom, and thus exist as two $\mathrm{R}$ and $\mathrm{S}$ enantiomers ${ }^{28}$.

On the other hand, SGAR molecules have two asymmetric carbons and each of them can be in $\mathrm{R}$ or $\mathrm{S}$ configuration $^{29,30}$. Thus, SGAR molecules exist as four stereoisomers with asymmetric carbons (i.e., $\mathrm{C} 1$ and $\mathrm{C} 3$ ) being in $\mathrm{R} / \mathrm{R}, \mathrm{R} / \mathrm{S}$, $\mathrm{S} / \mathrm{R}$ or $\mathrm{S} / \mathrm{S}$ configuration. The $1 \mathrm{R} / 3 \mathrm{R}$ and $1 \mathrm{~S} / 3 \mathrm{~S}$ configuration molecules are not superimposable and the image of the $1 R / 3 R$ molecule in a mirror corresponds to the $1 \mathrm{~S} / 3 \mathrm{~S}$ molecule. Both molecules are therefore enantiomers (Figure 2). This is the same for the $1 \mathrm{R} / 3 \mathrm{~S}$ and $1 \mathrm{~S} / 3 \mathrm{R}$ configuration molecules. For such molecules with two asymmetry centers, diastereomerism occurs when two or more stereoisomers of a compound have different configurations at one of the equivalent stereocenters 
and are not mirror images of each other ${ }^{25}$. Thus the $1 \mathrm{R} / 3 \mathrm{~S}$ and the $1 \mathrm{~S} / 3 \mathrm{R}$ stereoisomers are diastereoisomers of the $1 \mathrm{R} / 3 \mathrm{R}$ stereoisomer, but also of the $1 \mathrm{~S} / 3 \mathrm{~S}$ stereoisomer (Figure 2 and 3). Unlike enantiomers, diastereoisomers have different chemical and physical properties in a symmetric environment.

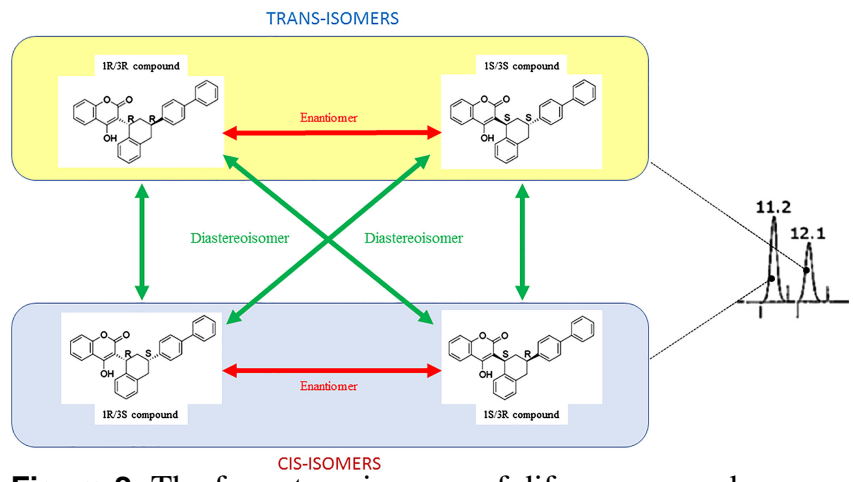

Figure 2. The four stereoisomers of difenacoum and separation by non-chiral chromatography using C18-reverse phase column.

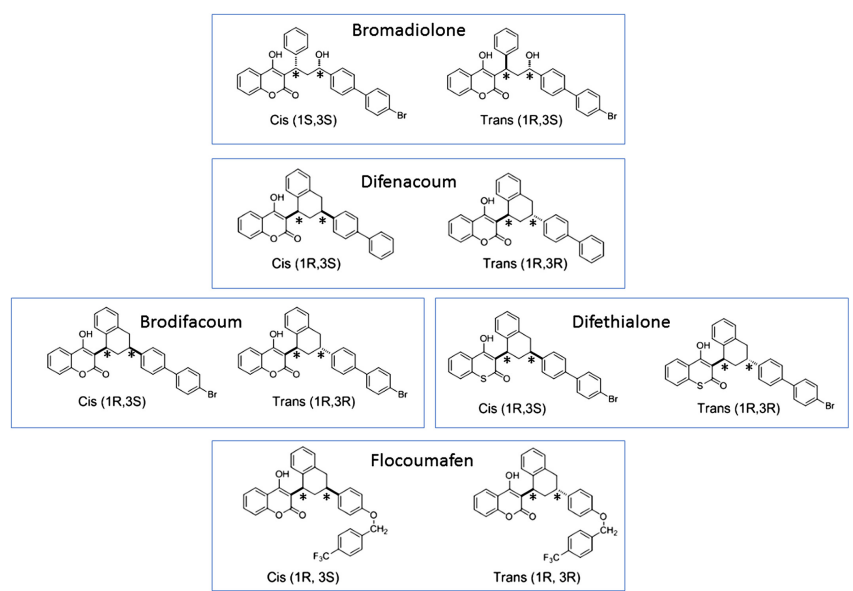

Figure 3. Diastereosisomers of SGARs with asymmetric carbon atoms highlighted.

It is often relatively easy to separate diastereoisomers by non-chiral chromatography using classical column (i.e., by using normal- or reverse-phase) and when separating a racemic mixture containing 4 stereoisomers of the same molecule with two asymmetry centers, two peaks can be obtained ${ }^{31}$, each of them containing a pair of enantiomers (Figure 2). Nevertheless, from a biological sample, the fact of observing both chromatographic peaks corresponding to the diastereoisomers does not give information on the ratio of the enantiomers within each of the peaks.

\section{Numerous examples of different biological properties among stereoisomers}

Biological systems are systematically composed of asymmetric molecules such as proteins or carbohydrates. If interaction between one protein and its ligand is allowed due to at least three molecular interaction bindings, this interaction can be different between enantiomers. Membrane transport, plasma transport, enzymatic metabolism, interaction with the pharmacological target ${ }^{2}$, etc. may be qualified as enantioselective phenomena.

Numerous examples of different biological properties among stereoisomers are available ${ }^{32-39}$. Drugs including both enantiomers in racemic proportion are often only active through a single enantiomer ${ }^{32,38,39}$. Moreover, the enantiomer that is not active may be sometimes harmful. ${ }^{37}$ Since interconversion between enantiomers is classically reported it is sometimes useless to synthesize, and thus administer, only one of the enantiomers under the pretext that it is the only active or the only one supporting a particular biological activity ${ }^{36}$.

A common and particularly interesting example in the context of rodents management is that of warfarin, which is an anticoagulant used as rodenticide and in human medicine to treat or prevent thromboembolic disorders. Warfarin is used as a racemic mixture of the two $\mathrm{R}$ - and $\mathrm{S}$-enantiomers. The main part of the pharmacodynamic properties is due to the $\mathrm{S}$-enantiomer. The metabolism of warfarin is enantioselective and regioselective ${ }^{33}$. S-warfarin is mainly oxidized by cytochrome P450 (CYP) 2C9 which produces 6 or 7 hydroxy$\mathrm{S}$-warfarin while R-warfarin is metabolized by CYP1A1, 1A2 and 3A4 producing 6-, 8-, 10-hydroxy-warfarin (Figure 4). The polymorphism of CYP2C9 gene has serious consequences on the therapeutic efficacy of warfarin. Common variants of this gene (i.e., the CYP2C9*2 and CYP2C9*3) oxidizes Swarfarin with limited (for the CYP2C9*2) or very limited efficiency (for the CYP2C9*3) ${ }^{34}$. Consequently, human patients homozygous for the CYP2C9*3 gene present a reduced clearance for $\mathrm{S}$-warfarin and a limited requirement of warfarin to obtain the therapeutic effect.

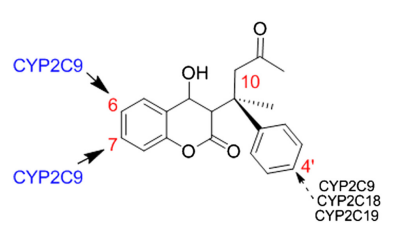

Metabolism pathway of S-WARFARIN

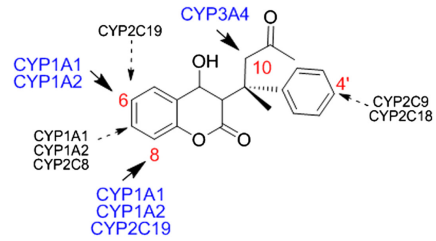

Metabolism pathway of R-WARFARIN
Figure 4. Oxidative metabolism of R- and S-warfarin.

\section{What about SGARs ?}

SGARs are always a mixture of four stereoisomers in commercial baits and proportions among stereoisomers are set by the relevant authorities through the given approvals. What 


\begin{tabular}{lcccc}
\hline & \multicolumn{2}{c}{ Trans-isomers } & \multicolumn{2}{c}{ Cis-isomers } \\
& \multicolumn{1}{c}{ identity } & proportion & identity & proportion \\
\hline Bromadiolone & $(1 \mathrm{R} / 3 \mathrm{~S})(1 \mathrm{~S} / 3 \mathrm{R})$ & $>70 \%$ & $(1 \mathrm{R} / 3 \mathrm{R})(1 \mathrm{~S} / 3 \mathrm{~S})$ & $<30 \%$ \\
Difenacoum & $(1 \mathrm{R} / 3 \mathrm{R})(1 \mathrm{~S} / 3 \mathrm{~S})$ & 20 to $50 \%$ & $(1 \mathrm{R} / 3 \mathrm{~S})(1 \mathrm{~S} / 3 \mathrm{R})$ & 50 to $80 \%$ \\
Brodifacoum & $(1 \mathrm{R} / 3 \mathrm{R})(1 \mathrm{~S} / 3 \mathrm{~S})$ & 20 to $50 \%$ & $(1 \mathrm{R} / 3 \mathrm{~S})(1 \mathrm{~S} / 3 \mathrm{R})$ & 50 to $80 \%$ \\
Flocoumafen & $(1 \mathrm{R} / 3 \mathrm{R})(1 \mathrm{~S} / 3 \mathrm{~S})$ & 20 to $50 \%$ & $(1 \mathrm{R} / 3 \mathrm{~S})(1 \mathrm{~S} / 3 \mathrm{R})$ & 50 to $80 \%$ \\
Difethialone & $(1 \mathrm{R} / 3 \mathrm{R})(1 \mathrm{~S} / 3 \mathrm{~S})$ & $<30 \%$ & $(1 \mathrm{R} / 3 \mathrm{~S})(1 \mathrm{~S} / 3 \mathrm{R})$ & $>70 \%$ \\
\hline
\end{tabular}

Table 1. Composition of SGAR molecules set by authorities.

\begin{tabular}{lcc}
\hline SGAR & Diastereoisomer & Half-life (h) \\
\hline Bromadiolone & Trans-isomers & 75 \\
& Cis-isomers & 27 \\
Difenacoum & Trans-isomers & 24 \\
& Cis-isomers & 78 \\
Brodifacoum & Trans-isomers & 69 \\
& Cis-isomers & 121 \\
Difethialone & Trans-isomers & 53 \\
& Cis-isomers & 72 \\
Flocoumafen & Trans-isomers & 177 \\
& Cis-isomers & 77 \\
\hline
\end{tabular}

Table 2. Half-life of cis- and trans-isomers of SGAR molecules in 8 -week old male Sprague-Dawley rats ${ }^{30}$. The major pair of stereoisomers present in the commercial preparation is highlighted in bold.

is set is the proportion between diastereoisomers ${ }^{40-44}$ (Table 1). For example, bromadiolone is a mixture of more than $70 \%(1 \mathrm{R} / 3 \mathrm{~S})(1 \mathrm{~S} / 3 \mathrm{R})$-isomers (both that can be also referred to as trans-isomers for bromadiolone) and less than $30 \%(1 \mathrm{R} / 3 \mathrm{R})(1 \mathrm{~S} / 3 \mathrm{~S})$-isomers (both that can be also referred to as cis-isomers for bromadiolone). Because syntheses of SGAR are carried out in an achiral environment, proportions between enantiomers are probably identical within a pair of diastereoisomers. That means, for example, bromadiolone in baits is composed of more than $70 \%$ of trans-isomers with equal proportions of 1R/3S- and 1S/3R-stereoisomers and less than $30 \%$ of cis-isomers with equal proportions of $1 \mathrm{R} / 3 \mathrm{R}$ - and 1S/3S-stereoisomers.

Because biological properties of each stereoisomer may be different, biological properties (i.e., efficacy, tissue persistence, or even reprotoxicity) of SGAR molecules, are a reflection of the biological properties of the 4 stereoisomers mixed according to the proportions currently defined by the approvals. Modification of stereoisomers proportions should modify biological properties of the mix. The evolution of these proportions can be done only after very precise characterization of the properties of each stereoisomer. Nevertheless this is difficult because of the necessity to obtain each stereoisomer independently. For this, stereoselective chemical syntheses or purifications using chiral phases are necessary but unfortunately often difficult and expensive without the success being certain (Table 2).

The interest in the concept and the possibility of modifying the properties of the SGARs to overcome the problems associated with their application in rodent management were therefore first of all addressed by the study of the biological properties of the pairs of cis- and trans-isomers. It could be shown that :

1. a diastereoisomeric pair is not converted in vivo into the other pair, whether it is the cis-isomers pair or the trans-isomers pair for all SGAR molecules. It is therefore quite possible to modify the biological properties of SGARs by modifying the proportions between diastereoisomers $^{29,30}$.

2. the efficiency to inhibit the VKORC1 enzyme, which is the target of ARs, is identical between diastereoisomeric pairs of SGARs in warfarin-susceptible rats ${ }^{29,30}$. This suggests that modifications of proportions between diastereoisomeric pairs should not affect the efficacy of SGAR molecules. Nevertheless, the characterization of the efficacy of stereoisomers is only beginning. Indeed, this evaluation has been reported for the moment only for warfarin-susceptible rats for cis- and trans-isomers. It seems therefore necessary to continue this evaluation for the 4 stereoisomers considered individually and no longer 2 by 2 , in rats but also in other rodents whose populations must be controlled, and especially in AR-resistant rodents. Indeed, mutations of VKORC1 supporting resistance are numerous and very varied between rodent species ${ }^{1,2,5}$.

3. systematically, regardless of the SGAR considered, a diastereomeric pair has a half-life lower than that of the other pair in rats ${ }^{29,30}$. The couple that is the most persistent is consistently the one that is most abundant in the composition currently approved, except for flocoumafen. More than $70 \%$ of bromadiolone is represented by trans-isomers according to the European product types 41 , while their half-life when administered together in identical proportion is 3 times longer than that of cis-isomers together ${ }^{30}$.

The reasons which led to the systematic registration of a mixture containing mainly the most persistent diastereoisomeric pair have never been discussed in the scientific community. We could assume that such ratios resulted from the need to kill the rodent after a single dose when these SGAR were developed by enriching the mix with either the most potent inhibitor or the most persistent pair of diastereomer and that single feeding was an important step forward for management.

The homologation of a new molecule containing only the 
least persistent diastereoisomeric pair or simply, for the sake of convenience, enriched with the least persistent diastereoisomeric pair would allow a faster elimination of the SGAR residues from the body of rats. This would reduce the amount of SGAR residues ingested by a predator or scavenger consuming a moribund or even dead intoxicated rat and would undoubtedly contribute to reducing secondary poisoning ${ }^{29,30}$. Moreover, within a pair of diastereoisomer, one enantiomer could present different biological properties compared to the other one. Again, the 4 stereoisomers must be considered individually and no longer 2 by 2 .

\section{Conclusions}

Before evolving definitively towards a modification of the proportions between the stereoisomers in the context of rodent management, an extension of the concept is necessary. Indeed, the change in proportions must lead to a new molecule that is less persistent in all rodents, but also in non-target species susceptible to being exposed to SGARs. The pharmacokinetic studies needed to definitively answer this question are difficult or impossible to implement in all potential non-target species. The use of model species such as japanese quail (Coturnix japonica), dogs (Canis familiaris), etc. could be considered. Furthermore, the technological advances in analytical chemistry make it possible to evolve towards highly specific and highly sensitive analytical methods able to detect and quantify the various stereoisomers of SGARs in various complex biological matrices (liver, blood, eggs, etc.) collected in nontarget species exposed to SGARs ${ }^{31}$. The development of such a method has already allowed us to evaluate the proportions between diastereoisomeric pairs of SGAR in different species such as wild Norway rat (Rattus norvegicus), red kite (Milvus milvus) and red fox (Vulpes vulpes). Only trans-isomers of bromadiolone were detected in liver of red kites ${ }^{45}$ or red foxes ${ }^{46}$ poisoned or exposed to bromadiolone, confirming elimination of cis-isomers by the double filter composed of the target and the non-target species. This monitoring in wildlife will enable to contribute to the identification of the least ecotoxic stereoisomer of SGARs and thus to enrich SGAR molecules with this stereoisomer to reduce ecotoxicity associated to ARs.

The use of a stereoisomer or a mixture of stereoisomers which allows 1/ a faster elimination of the SGAR residues from the body of rodents and $2 /$ a fast elimination by the predators or the scavengers could highly reduce the ecotoxicity of these modified SGAR. This way of improvement could represent the chemical alternative expected by the European authorities and professionals.

\section{Acknowledgements}

This work was supported by grants ISI $n^{\circ} \mathrm{I} 1301001 \mathrm{~W}$ "NEORAMUS" from Bpi France.

\section{References}

[1] Simone Rost et al. "Mutations in VKORC1 Cause Warfarin Resistance and Multiple Coagulation Factor Deficiency Type 2". In: Nature 427.6974 (Feb. 5, 2004), pages 537-541. ISSN: 1476-4687. DOI: 10 . $1038 /$ nature 02214 . pmid: 14765194 (cited on pages 1, 4).

[2] Hans-Joachim Pelz et al. "The Genetic Basis of Resistance to Anticoagulants in Rodents". In: Genetics 170.4 (Aug. 2005), pages 1839-1847. ISSN: 0016-6731. DOI: $10.1534 /$ genetics. 104.040360 (cited on pages $1,3,4)$.

[3] Agnes Grandemange et al. "Consequences of the Y139F Vkorc1 Mutation on Resistance to AVKs: InVivo Investigation in a 7th Generation of Congenic Y139F Strain of Rats". In: Pharmacogenet. Genomics 19.10 (Oct. 2009), pages 742-750. ISSN: 1744-6872. DOI: 10.1097 / FPC . 0b013e32832ee55b. pmid: 19752778 (cited on page 1).

[4] Ahmed Hodroge et al. "Biochemical Characterization of Spontaneous Mutants of Rat VKORC1 Involved in the Resistance to Antivitamin K Anticoagulants". In: Arch. Biochem. Biophys. 515.1-2 (Nov. 2011), pages 14-20. ISSN: 1096-0384. DOI: $10.1016 / j$. abb. 2011.08 .010 pmid: 21907178 (cited on page 1).

[5] Joffrey Goulois et al. "Adaptative Evolution of the Vkorc1 Gene in Mus Musculus Domesticus Is Influenced by the Selective Pressure of Anticoagulant Rodenticides". In: Ecology and Evolution (2017). DOI: 10.1002 / ece3.2829 (cited on pages 1,4).

[6] J. Hughes et al. "Monitoring Agricultural Rodenticide Use and Secondary Exposure of Raptors in Scotland". In: Ecotoxicology 22.6 (Aug. 2013), pages 974-84. ISSN: 1573-3017 (ELECTRONIC) 0963-9292 (LINKING). DOI: 10 . 1007 / s10646-013-1074-9. PMID: 23595554 (cited on pages 1,2).

[7] Marion Jacquot et al. "Using Long-Term Monitoring of Red Fox Populations to Assess Changes in Rodent Control Practices". In: J Appl Ecol 50.6 (Dec. 1, 2013), pages 1406-1414. ISSN: 1365-2664. DOI: $10.1111 /$ 1365-2664.12151 (cited on pages 1, 2).

[8] Francesca Caloni et al. "Suspected Poisoning of Domestic Animals by Pesticides". In: Science of The Total Environment 539 (Jan. 2016), pages 331-336. ISSN: 00489697. Dor: $10.1016 / j$. scitotenv . 2015. 09.005 (cited on page 1).

[9] Jens Jacob and Alan Buckle. "Use of Anticoagulant Rodenticides in Different Applications Around the World". In: Anticoagulant Rodenticides and Wildlife. Edited by Nico W. van den Brink et al. Emerging Topics in Ecotoxicology. Cham: Springer International Publishing, 
2018, pages 11-43. ISBN: 978-3-319-64377-9. DOI: $10.1007 / 978-3-319-64377-9{ }_{2}$ (cited on page 1$)$.

[10] C. Mary Boyle. "Case of Apparent Resistance of Rattus Norvegicus Berkenhout to Anticoagulant Poisons". In: Nature 188.4749 (1960), pages 517-517. DOI: 10 . $1038 / 188517$ a 0 (cited on page 1).

[11] E. DODSWORTH. "Mice Are Spreading despite Such Poisons as Warfarin”. In: Minic. Engin. Lond. 3746 (1961), page 1668. URL: http: / / ci . nii.ac . jp/naid/10029767205/(cited on page 1).

[12] William Jackson and Dale Kaukeinen. "THE PROBLEM OF ANTICOAGULANT RODENTICIDE RESISTANCE IN THE UNITED STATES”. In: Proceedings of the 5th Vertebrate Pest Conference (1972) (Mar. 1, 1972). URL: https: / / digitalcommons . unl. edu/vpc5/27 (cited on page 1).

[13] Z. Siddiq and W. D. Blaine. "Anticoagulant Resistance in House Mice in Toronto, Canada.” In: 32 (1982), pages $49-51$ (cited on page 1 ).

[14] Kazuyuki D. Tanaka et al. "The Genetic Mechanisms of Warfarin Resistance in Rattus Rattus Found in the Wild in Japan". In: Pesticide Biochemistry and Physiology 103.2 (June 2012), pages 144-151. ISSN: 0048-3575. DOI: $10.1016 / j \cdot$ pestbp.2012.04.011 (cited on page 1).

[15] G. R. Saunders. "Resistance to Warfarin in the Roof Rat in Sydney." In: 9 (1978), pages 39-40 (cited on page 1).

[16] Christine Fournier-Chambrillon et al. "Evidence of Secondary Poisoning of Free-Ranging Riparian Mustelids by Anticoagulant Rodenticides in France: Implications for Conservation of European Mink (Mustela Lutreola)". In: J. Wildl. Dis. 40.4 (Oct. 2004), pages 688695. ISSN: 0090-3558. DOI: 10 . 7589/0090-355840.4 .688 . pmid: 15650086 (cited on page 2).

[17] L. E. K. Serieys et al. "Anticoagulant Rodenticides in Urban Bobcats: Exposure, Risk Factors and Potential Effects Based on a 16-Year Study". In: Ecotoxicology 24.4 (May 2015), pages 844-862. ISSN: 1573-3017. DOI: 10.1007 / s10646-015-1429-5. pmid: 25707484 (cited on page 2).

[18] M. Elmeros, T. K. Christensen, and P. Lassen. "Concentrations of Anticoagulant Rodenticides in Stoats Mustela Erminea and Weasels Mustela Nivalis from Denmark". In: The Science of the total environment 409.12 (May 15, 2011), pages 2373-8. ISSN: 18791026 (ELECTRONIC) 0048-9697 (LINKING). DOI: $10.1016 /$ j. scitotenv . 2011.03 .006$. PMID: 21477845 (cited on page 2).
[19] Anke Geduhn et al. "Relation between Intensity of Biocide Practice and Residues of Anticoagulant Rodenticides in Red Foxes (Vulpes Vulpes)". In: PLOS ONE 10.9 (Sept. 29, 2015). Edited by Pieter Spanoghe, e0139191. ISSN: 1932-6203. DOI: 10 . $1371 /$ journal. pone. 0139191 (cited on page 2).

[20] V. Vandenbroucke et al. "Pharmacokinetics of Eight Anticoagulant Rodenticides in Mice after Single Oral Administration". In: Journal of veterinary pharmacology and therapeutics 31.5 (Oct. 2008), pages 437-45. ISSN: 1365-2885 (ELECTRONIC) 0140-7783 (LINKING). DOI: $10.1111 / j .1365-2885.2008$. 00979 .x. PMID: 19000263 (cited on page 2).

[21] Johannes Oldenburg et al. "The Vitamin K Cycle". In: Vitam Horm 78 (2008), pages 35-62. ISSN: 00836729. DOI: $10.1016 / \mathrm{s} 0083-6729(07) 00003-9$ (cited on page 2 ).

[22] J. G. Hall, R. M. Pauli, and K. M. Wilson. "Maternal and Fetal Sequelae of Anticoagulation during Pregnancy". In: Am. J. Med. 68.1 (Jan. 1980), pages 122140. ISSN: 0002-9343. pmid: 6985765 (cited on page 2).

[23] Dieneke Van Driel et al. "Teratogen Update: Fetal Effects after in Utero Exposure to Coumarins Overview of Cases, Follow-up Findings, and Pathogenesis". In: Teratology 66.3 (Sept. 2002), pages 127-140. ISSN: 0040-3709. DOI: 10.1002 / tera . 10054 . pmid: 12210474 (cited on page 2).

[24] R. Kappeler and F. Koller. "[Intravenous administration of vitamin K1 (konakion) as antidote to the anticoagulants of the dicumarol type]". In: Schweiz Med Wochenschr 85.3 (Jan. 15, 1955), pages 62-64. ISSN: 0036-7672. pmid: 14358604 (cited on page 2).

[25] Lien Ai Nguyen, Hua He, and Chuong Pham-Huy. "Chiral Drugs: An Overview". In: Int J Biomed Sci 2.2 (June 2006), pages 85-100. ISSN: 1550-9702. URL: http : / / www - ncbi - nlm . nih - gov / pmc / articles/PMC3614593/ (visited on 10/26/2015) (cited on pages 2, 3).

[26] Ronald D. McKelvey. "Stereochemistry of Organic Compounds ( Eliel, Ernest L.; Wilen, Samuel H.)” In: J. Chem. Educ. 73.8 (Aug. 1, 1996), A174. ISSN: 00219584. DOI: 10.1021 / ed073pA174.2 (cited on page 2).

[27] R. S. Cahn, C. K. Ingold, and V. Prelog. "The Specification of Asymmetric Configuration in Organic Chemistry". In: Experientia 12.3 (Mar. 1, 1956), pages 8194. ISSN: 1420-9071. DOI: 10.1007 / BF 02157171 (cited on page 2). 
[28] I. A. Choonara et al. "Enantiomers of Warfarin and Vitamin K1 Metabolism”. In: Br J Clin Pharmacol 22.6 (Dec. 1986), pages 729-732. ISSN: 0306-5251. DOI: $10.1111 / j .1365-2125.1986 . t b 02966 . x$. pmid: 3567019 (cited on page 2).

[29] Marlène Damin-Pernik et al. "Development of an Ecofriendly Anticoagulant Rodenticide Based on the Stereochemistry of Difenacoum". In: Drug Metab. Dispos. 44.12 (Dec. 2016), pages 1872-1880. ISSN: 1521009X. DOI: 10.1124 / dmd . 116.071688 . pmid: 27621204 (cited on pages 2, 4, 5).

[30] Marlène Damin-Pernik et al. "Management of Rodent Populations by Anticoagulant Rodenticides: Toward Third-Generation Anticoagulant Rodenticides". In: Drug Metab Dispos 45.2 (Feb. 1, 2017), pages 160165. ISSN: 0090-9556, 1521-009X. DOI: 10.1124 / dmd . 116.073791 . pmid: 27934637 (cited on pages 2, 4, 5).

[31] Isabelle Fourel et al. "Core-Shell LC-MS/MS Method for Quantification of Second Generation Anticoagulant Rodenticides Diastereoisomers in Rat Liver in Relationship with Exposure of Wild Rats". In: Journal of Chromatography B 1041-1042 (Jan. 2017), pages 120132. ISSN: 15700232 . DOI: $10.1016 / j$. jchromb. 2016.12 .028 (cited on pages 3, 5).

[32] Katharina M. Rentsch. "The Importance of Stereoselective Determination of Drugs in the Clinical Laboratory". In: Journal of Biochemical and Biophysical Methods. Heftmann 2002 S.I. - Chromatography of Chiral Drugs 54.1 (Dec. 31, 2002), pages 1-9. ISSN: 0165-022X. DOI: 10 . 1016/S0165-022X(02) 00124-0 (cited on page 3 ).

[33] L. S. Kaminsky and Z. Y. Zhang. "Human P450 Metabolism of Warfarin". In: Pharmacol. Ther. 73.1 (1997), pages 67-74. ISSN: 0163-7258. pmid: 9014207 (cited on page 3 ).

[34] Suman Lal et al. "Pharmacogenetics of Target Genes Across the Warfarin Pharmacological Pathway". In: Clin Pharmacokinet 45.12 (Dec. 1, 2006), pages 11891200. ISSN: 1179-1926. DOI: 10 . 2165/00003088200645120-00004 (cited on page 3).

[35] Eugène Baltes et al. "Absorption and Disposition of Levocetirizine, the Eutomer of Cetirizine, Administered Alone or as Cetirizine to Healthy Volunteers". In: Fundamental \& Clinical Pharmacology 15.4 (2001), pages 269-277. ISSN: 1472-8206. DOI: $10.1046 / \mathrm{j}$. 1472-8206.2001.00035.x (cited on page 3).

[36] Hiroyuki Ikuta, Atsushi Kawase, and Masahiro Iwaki. "Stereoselective Pharmacokinetics and Chiral Inversion of Ibuprofen in Adjuvant-Induced Arthritic Rats". In: Drug Metab Dispos 45.3 (Mar. 1, 2017), pages 316324. ISSN: 0090-9556, 1521-009X. DOI: 10.1124 / dmd . 116.073239. pmid: 27927688 (cited on page 3).

[37] Tommy Eriksson et al. "Stereospecific Determination, Chiral Inversion in Vitro and Pharmacokinetics in $\mathrm{Hu}$ mans of the Enantiomers of Thalidomide". In: Chirality 7.1 (1995), pages 44-52. ISSN: 1520-636X. DOI: 10.1002 / chir. 530070109 (cited on page 3).

[38] Peter Hayball. "Chirality and Nonsteroidal AntiInflammatory Drugs”. In: Drugs 52.5 (Nov. 1, 1996), pages 47-58. ISSN: 1179-1950. DOI: $10.2165 /$ 00003495-199600525-00006 (cited on page 3).

[39] Luciano Ribeiro Pinto et al. "Eszopiclone versus Zopiclone in the Treatment of Insomnia". In: Clinics (Sao Paulo) 71.1 (Jan. 2016), pages 5-9. ISSN: 1807-5932. DOI: 10 . 6061/clinics / 2016 (01) 02. pmid: 26872077 (cited on page 3).

[40] Commission Directive 2007/69/EC of 29 November 2007 Amending Directive 98/8/EC of the European Parliament and of the Council to Include Difethialone as an Active Substance in Annex I Thereto (Text with EEA Relevance). Nov. 30, 2007. URL: http: / / data . europa.eu/eli/dir/2007/69/oj/eng (visited on 02/07/2020) (cited on page 4).

[41] Commission Directive 2009/92/EC of 31 July 2009 Amending Directive 98/8/EC of the European Parliament and of the Council to Include Bromadiolone as an Active Substance in Annex I Thereto (Text with EEA Relevance). Aug. 1, 2009. URL: http : / / data . europa.eu/eli/dir/2009/92/oj/eng (visited on 02/07/2020) (cited on page 4).

[42] Commission Directive 2010/10/EU of 9 February 2010 Amending Directive 98/8/EC of the European Parliament and of the Council to Include Brodifacoum as an Active Substance in Annex I Thereto (Text with EEA Relevance). Feb. 10, 2010. URL: http : / / data . europa.eu/eli/dir/2010/10/oj/eng (visited on 02/07/2020) (cited on page 4).

[43] Commission Directive 2008/81/EC of 29 July 2008 Amending Directive 98/8/EC of the European Parliament and of the Council to Include Difenacoum as an Active Substance in Annex I Thereto (Text with EEA Relevance). July 30, 2008. URL: http : / / data . europa.eu/eli/dir/2008/81/oj/eng (visited on 02/07/2020) (cited on page 4).

[44] Commission Directive 2009/150/EC of 27 November 2009 Amending Directive 98/8/EC of the European Parliament and of the Council to Include Flocoumafen as an Active Substance in Annex I Thereto (Text with EEA Relevance). Nov. 28, 2009. URL: http: / / data . europa . eu / eli / dir / 2009 / 150 / oj / eng (visited on 02/07/2020) (cited on page 4). 
[45] Isabelle Fourel et al. "Cis-Bromadiolone Diastereoisomer Is Not Involved in Bromadiolone Red Kite (Milvus Milvus) Poisoning". In: Science of The Total Environment 601-602 (Dec. 1, 2017), pages 1412-1417. ISSN: 0048-9697. DoI: $10.1016 /$ j.scitotenv. 2017 . 06.011 (cited on page 5).

[46] Isabelle Fourel et al. "Liver and Fecal Samples Suggest Differential Exposure of Red Fox (Vulpes Vulpes) to Trans- and Cis-Bromadiolone in Areas from France Treated with Plant Protection Products". In: Science of The Total Environment 622-623 (May 1, 2018), pages 924-929. ISSN: 0048-9697. DOI: 10 . $1016 /$ j.scitotenv.2017.12.053 (cited on page 5). 